\title{
Hledání Mistra - dva rané klavírní koncerty Jana Nováka
}

\section{In Search of a Master - Two Early Piano Concertos by Jan Novák}

Martin Flašar / flasar@phil.muni.cz

Department of Musicology, Faculty of Arts, Masaryk University, Brno, CZ

Pavel Žůrek / pavel@martinu.cz

Bohuslav Martinů Institute, Prague, CZ

\begin{abstract}
The study compares two piano concertos by Jan Novák (1921-1984). Until now, it was believed that the composer was the author of only one piano concerto, which he reworked under the supervision of Bohuslav Martinů during his New York study stay at the turn of 1947-1948. Only a comparative analysis shows that these are two completely different compositions. While Novák left the first of them as a student work, the second represents a mature artwork strongly influenced by Bohuslav Martinů.
\end{abstract}

\section{Key words}

Jan Novák, Bohuslav Martinů, piano concerto, New York, comparative analysis 
Ve svém raném období tvorby v průběhu krátkém rozmezí dvou let 1947-1949 zkomponoval Novák dva klavírní koncerty. Tehdy vrcholila a končila jeho učednická léta, doba uměleckého formování, kdy upevňoval a rozvíjel svou skladatelskou techniku, které se naučil. Byla to však také doba hledání, jakou cestou se ve své tvưrčí poetice a estetice vydat, spojená s ochotou naslouchat slovu umělecké autority, která mu pomůže nalézt směr. Oba klavírní koncerty, z nichž první z roku 1947 dosud nebyl znám, dokládají jak zákruty oné cesty Novákova hledání, kterou tehdy procházel, tak jeho rázné vykročení novým směrem spojeným se zásadní proměnou jeho skladatelského myšlení.

\section{Kdos mistr můj? - Klavírní koncert z roku 1947}

„Potloukal jsem se světem dosti a bál jsem se, že snad zahynu..."1

Při shromažd’ování pramenů pro přípravu monografie Jan Novák a Bohuslav Martinů ve světle vzájemné korespondence (1947-1959) se autorům této studie podařilo identifikovat Novákův dosud neznámý raný koncert pro klavír a velký orchestr z roku 1947. Ke skladbě se v Novákově pozůstalosti uložené v Hudebněhistorickém oddělení Národního muzea Českého muzea hudby (bez signatury, přírůstkové číslo 141/1-4) dochovala skladatelova skica, část náčrtu partitury tužkou, autografní partitura, dobová reprodukce autografní partitury (dye-line copy) a Novákova úprava díla pro dva klavíry.

Podle svých zápisků začal Novák koncert komponovat někdy na podzim roku $1946 .{ }^{2}$ V té době se stal posluchačem 1. ročníku oboru hudební skladba na tehdy nově zřízené Akademii múzických umění v Praze. Je možné a pravděpodobné, že šlo o kompoziční úkol, který mu zadal jeho nový učitel skladby na AMU (nyní HAMU) Pavel Bořkovec. Poté, co v polovině 1. školního roku Novák přestoupil na nově založenou brněnskou pobočku AMU (nyní JAMU), vyučoval jej ve skladbě opět jeho staronový učitel Vilém Petrželka, pod jehož vedením v práci na skladbě od ledna 1947 pokračoval. S nedokončenou partiturou koncertu odjel Novák na letní studijní pobyt do Tanglewoodu, kde byl jeho lektorem hudební kompozice Aaron Copland. Koncert Novák dokončil pět dnů před první soukromou lekcí kompozice u Bohuslava Martinů (1890-1959), ke kterému docházel na soukromé hodiny skladby od září 1947 do února 1948. Autografní partituru psanou černým perem na transparentním papíru Novák dokončil v New Yorku 3. 9. 1947 a dílo nazval anglicky Piano concerto. Vzhledem k okolnostem, které budou popsány níže, nebyl koncert nikdy proveden, ač Novák původně plánoval nabídnout jeho premiéru Rudolfu Firkušnému. ${ }^{3}$

1 Třetí sonet Jana Nováka z cyklu Sonety na B. Martinů. In ZOUHAR, Zdeněk (ed.). Bohuslav Martinů. Sbornik vzpominek a studii. Krajské nakladatelství v Brně, 1957, s. 42.

2 NOVÁK, Jan. Poznámky z dopisů J. Nováka o lekcích u B. Martinů [rukopis]. Pozůstalost J. Nováka, ČMH Praha, New York, 8. 9. 1947.

3 „Ruda to asi proý hrát nebude, i kdyby se mu to nakrásně líbilo, tak asi jeho manager bude proti." Tamtéž. 
Novák Piano concerto instrumentoval pro symfonický orchestr velkého obsazení s výraznou sekcí perkusních nástrojů: flétna piccola, dvě flétny, 2 hoboje, anglický roh, 2 klarinety in B, 2 fagoty, kontrafagot, 4 lesní rohy in F, 3 trubky in C, 3 trombóny, tuba, tympány, tamburína, malý buben, velký buben, činely, gong, xylofon, celesta a smyčce.

\section{Formální plán}

Novák zvolil pro formální rozvrh koncertu obvyklé schéma třívětého cyklu s krajními rychlými a stř̌ední pomalou větou, kterou však ozvláštnil tím, že ji pojal jako variační Ciacconu.

1. Allegro (493 t.) - Es, C/ takt.

2. Ciaccona. Grave (48 t.). Poco più animato (58 t.). Tempo I. (34 t.) - B, 3/4 takt.

3. Molto allegro (339 t.) - 6/4 takt. Maestoso (16 t.) - 3/2 takt. - Es.

\section{1. věta (493 t.)}

První věta, Allegro v C/ taktu, oscilující kolem tonálního centra Es, je v sonátové formě se zřetelně oddělenými a výrazně vyhraněnými tématy. Ve své rytmické pregnanci formulované v oblasti hlavního tématu kombinované s širokodechou melodickou expozicí druhého a třetího tématu kombinuje zjevné inspirace Bachem a romantismem.

\section{Expozice}

Hlavní téma je rytmicky a melodicky výrazné a harmonicky krouží kolem Es s použitím bitonality (Ces dur/Es dur). Jeho bachovská melodika podpořená motorickým doprovodem osminkových figurací kráčivé basové linky, která je potom převzata postupně celým orchestrem, výrazně posiluje výslednou neobarokní stylizaci.

Bachovsky laděný je také sólový vstup klavíru v t. 15 melodicky odvozený z hlavního tématu, který se v rámci expozice několikrát vrací.

Zvolená neobarokní stylizace se poté projevuje v celé oblasti hlavního tématu až na krátkou epizodu sólového klavíru v t. 73-85, která připravuje závěr expozice hlavního tématu.

Oblast druhého tématu začíná v t. 95 materiálem odvozeným z hlavního tématu, který modulací vplyne ve výrazné lyrické téma v c moll t. 111-116.

Zároveň se Novákova stylizace všech jednotlivých hudebních složek posune k pseudoromantismu, který je patrný i v následném evolučním rozvoji oblasti druhého tématu. Závěrečné téma od t. 212 je organicky spjaté s lyrickým tématem. Po krátké mezivětě v t. 220-223 začíná provedení (od t. 224), které nejprve zpracovává oblast hlavního tématu, od t. 280 oblasti vedlejšího tématu. Repríza začíná v t. 308 doslovným návratem úvodní orchestrální části oblasti hlavního tématu, která se potom s návratem oddílu sólového klavíru evolučně rozvijí, což platí i o návratu vedlejš̌́ho (t. 351) a závěrečného tématu (t. 405). Po virtuózní sólové kadenci klavíru (t. 438-471) je první věta koncertu uzavřena codou (t. 470-491), která přináší opět evolučně rozšriřený návrat úvodního orchestrální části hlavního tématu. 


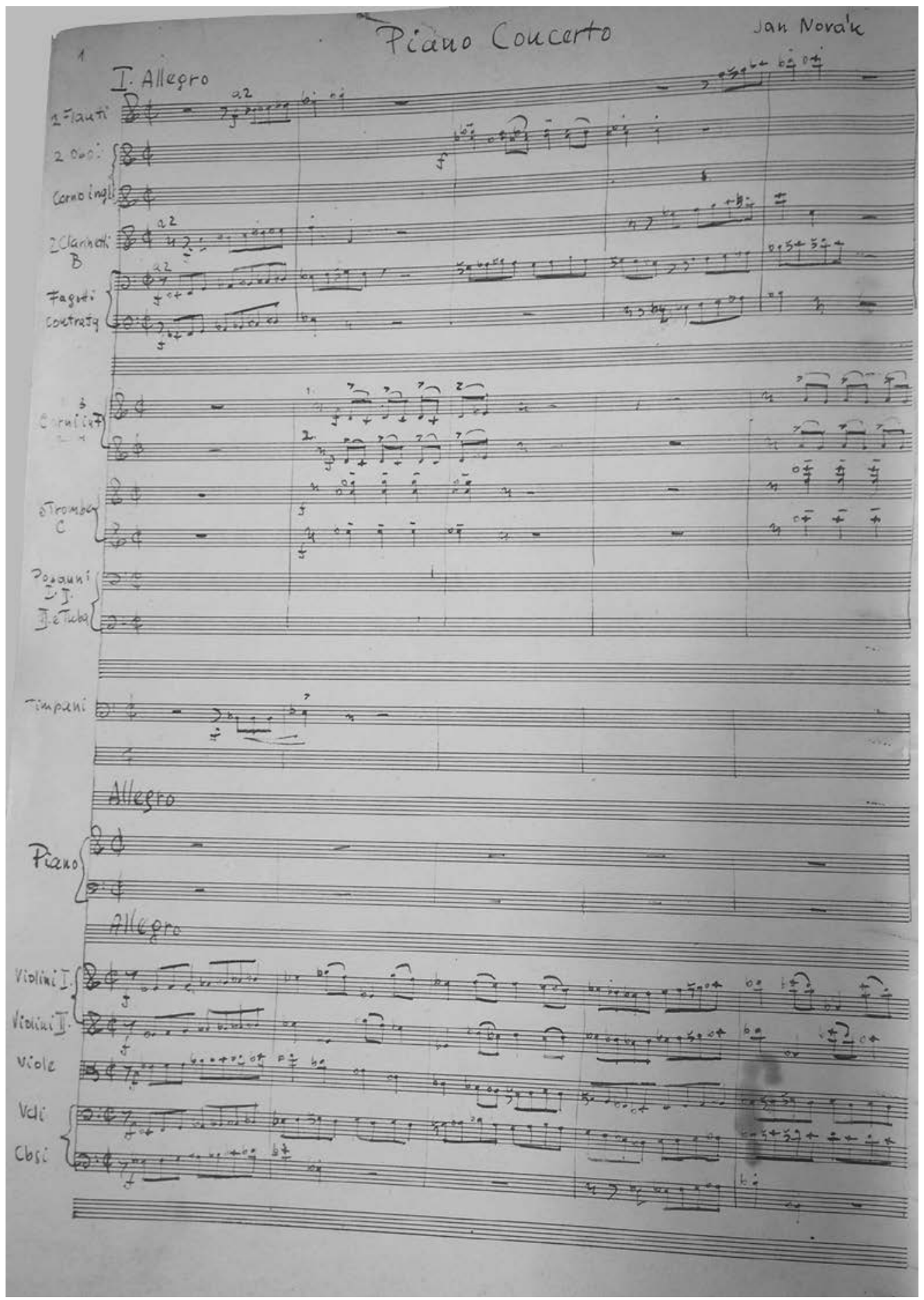

Př. 1 První věta, t. 1-5, dobová reprodukce Novákovy autografní partitury. 


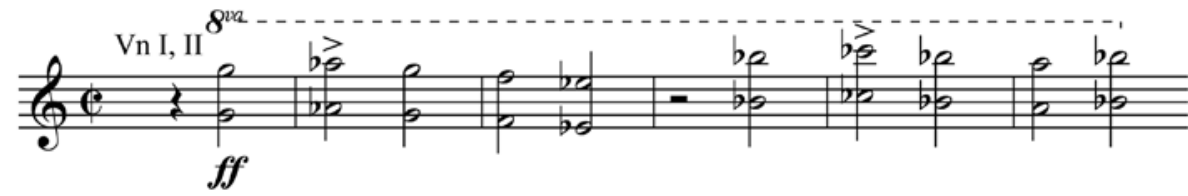

Př. 2 První věta, t. 111-116.

\section{2. věta (141 t.)}

Pro pomalou větu, Grave, která osciluje kolem tonálního centra v Bb, 3/4 takt, si Novák zvolil barokní variační formu ciacciony. Dalo by se však říci, že zařazením krátkého sólového kontrastního středního oddílu rapsodického charakteru se blíží pomalá věta dvoudílné formě.

Jednotlivé variace dílu probíhají nad osmitaktovým melodickým tématem v basu, které zůstává stále stejné.

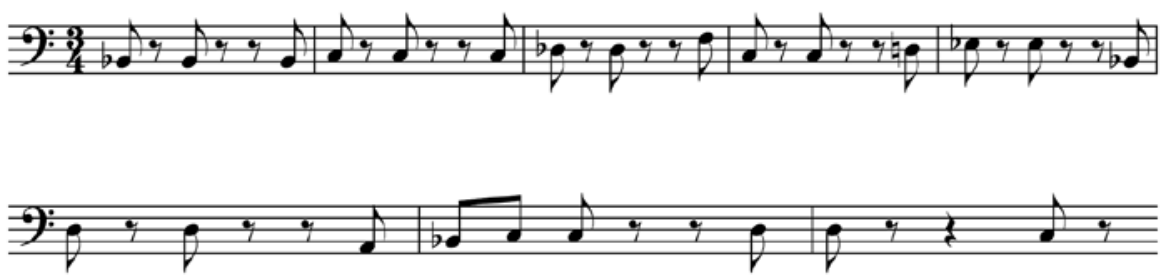

Př. 3 Druhá věta, téma Ciaccony.

V introdukci (t. 1-8) však Novák nechává zaznít téma v nejvyšším hlase pravé ruky sólového klavíru.

Po introdukci následuje v t. 9-72 osm variací. V 1. variaci přináší Vn II k basovému modelu ve Vc a Cb kontrastní téma, ke kterému se v dalších variacích přidávají kanonickými postupy další nástroje s kontrapunktickými hlasy a faktura i melodicko-tematický rozvoj graduje ve zdánlivě nastupující 9. variaci. Jde však už o součást přechodového úseku ke kontrastnímu střednímu oddílu. Po čtyřech taktech první poloviny melodického modelu, je v t. 77 pravidelný hudební tok náhle brutálně přerušen čtyřtaktovým dramaticky vypjatým úsekem v nepravidelném metru, který je již součástí kontrastního oddílu, přednášeném pouze sólovým klavírem, jež má rapsodický charakter (t. 78-83). V taktu 83 se hudební tok úplně uvolňuje z metrického schématu a Novák jej přestane členit taktovými čárami.

Po ritardandu, kterým končí kontrastní úsek, se vrací Novák k pokračování v přerušených variacích, nyní se zapojením celého orchestru. Uvede jich ještě sedm, přičemž opět směřuje ke gradaci ve 13. variaci. Na rozdíl od úvodní části je tato gradace od 12. variace vystavěna ryze na sólových virtuózních pasážích klavíru, kdy Vc a Cb přednášejí melodický model. 14. variaci představuje náznak reprízy, kdy se opět vrací kontrapunktické 
téma z 1. variace. Celá věta končí uvedeným samotného melodického modelu klavírem $\mathrm{v}$ hluboké basové poloze $\mathrm{v}$ pp rozšířeným dvěma závěrečnými takty opakující tón $\mathrm{b}$ do ztracena (perdendosi), který zaznívá též po celý závěr v doprovodu pouze Timp a $\mathrm{Cb}$ jako ostinato.

\section{3. věta (355 t.)}

Jestliže jsme mohli konstatovat na základě analýzy, že předchozí dvě věty koncertu jsou v podstatných rysech stylizovány neobarokně, potom o poslední větě lze právem říct, že představuje přerušení dosavadního zvolené stylizace, a je plně ovlivněn Novákovou recepcí díla Leoše Janáčka a s tím souvisejících neofolklorních inspirací. ${ }^{4}$ Tyto znaky se projevují převážně v melodice (užití pentatoniky, kvartové melodiky) a v rytmice (katalekticky formulované motivy) a lze v nich patrně spatřovat myšlenkový vliv Novákova tehdejšího staronového učitele kompozice Petrželky, který byl Janáčkovým žákem.

Formálně je třetí věta, Molto allegro, 6/4 takt, vystavěna jako rondo a osciluje kolem tonálního centra Es. V dílu A (t. 1-21) uvádí klavír úsečné pentatonicky formulované téma v Es, v doprovodu orchestru bitonálně zabarvené do $\mathrm{C}$ :

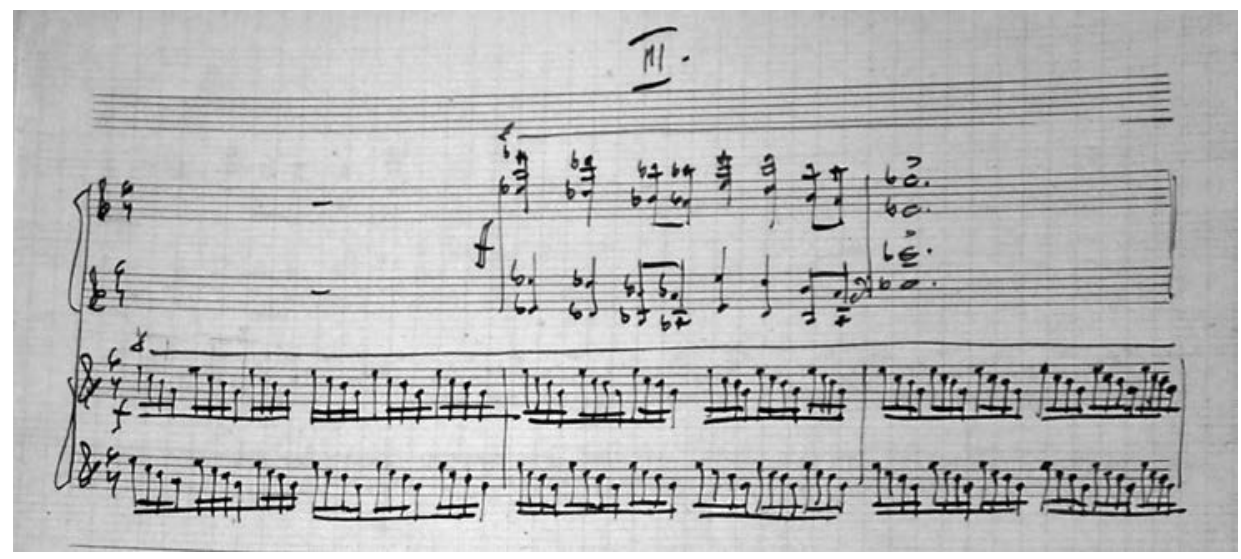

Př. 4 Tretí věta, t. 1-3, Novákův autografní klavírní výtah koncertu.

V dílu B (t. 22-44) se tonální centrum přesouvá o pưltón nahoru do E a lesní rohy přinášejí opět pentatonicky formulované téma doplněné komplementárním melodickým motivem $\mathrm{v}$ Tr.

V dílu A' (t. 45-58) se vrací téma, avšak evolučně zpracované technikou montáže, která je právě pro Janáčkovu tektonickou výstavbu, kterou se Novák zde zjevně inspiroval, typická, jak konstatoval Miloš Štědroň. ${ }^{5}$

Téma dílu C (t. 59-105) v as moll, představuje pro Janáčka typický typ sekund-kvartové melodiky ukončené úsečným rytmickým zkráceným motivem:

4 Dokladem Novákova zájmu o Janáčka jsou jeho klavírní Dvě preludia a fughetty na téma z opery Kát’a Kabanová z roku 1946.

5 Viz jeho analýzy v monografii ŠTĚDROŇ, Miloš. Leoš Janáček a hudba 20. století. Brno 1998, s. 147nn. 

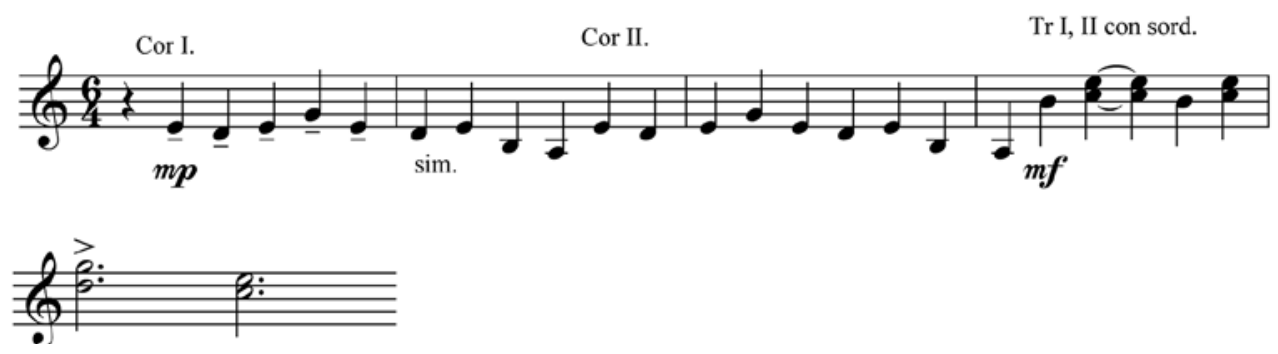

Př. 5 Třetí věta, t. 22-26.

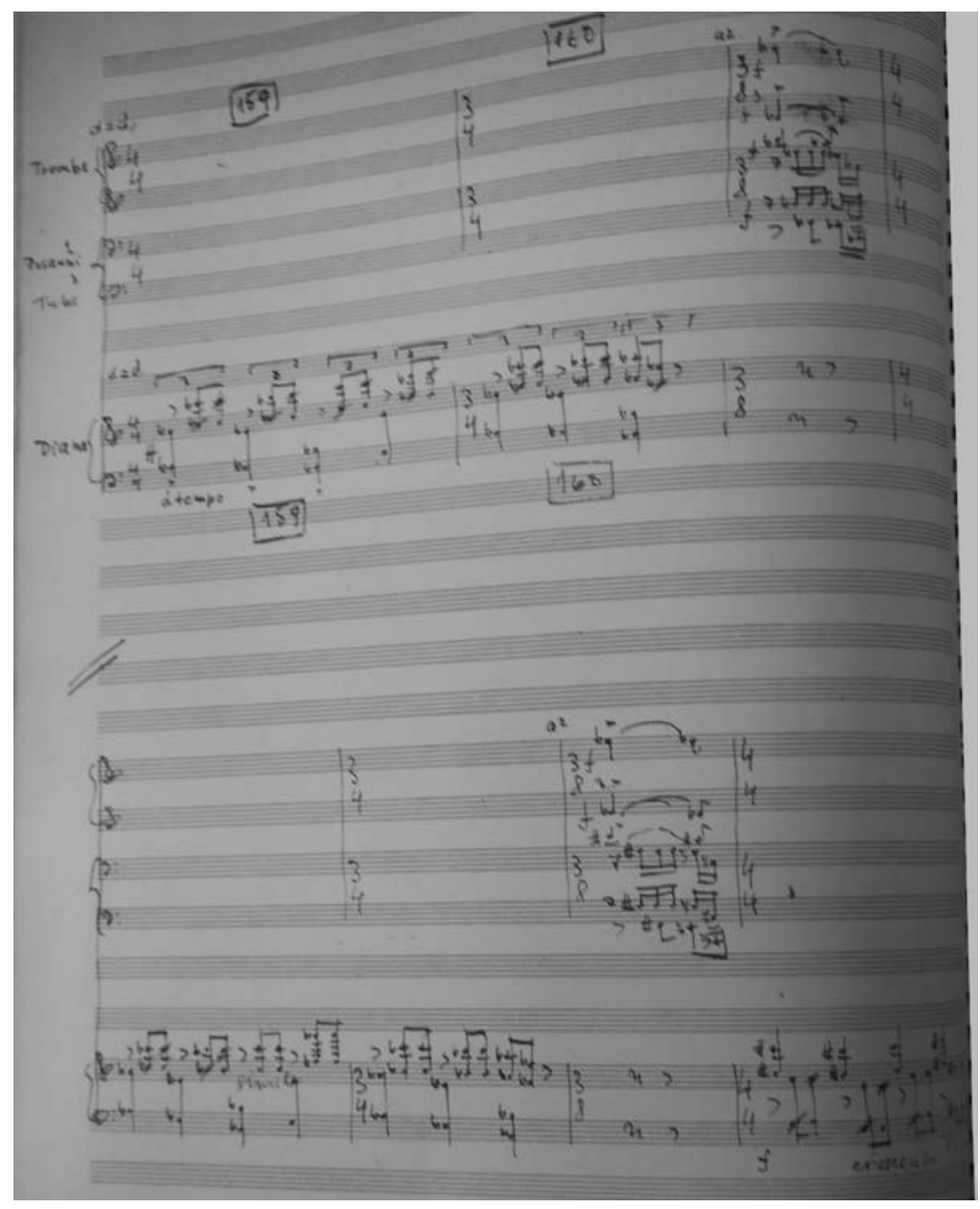

Př. 6 Třetí věta, t. 59-65, ${ }^{6}$ dobová reprodukce autografní partitury, jsou zde i pozdější Novákovy škrty modrou pastelkou.

6 Př̀ zápisu orientačních čísel ve 3. větě na s. 131 autografu Novák chybně označil t. 59 a 60 číslicemi 159 a 160 . 
Hlavní téma věty se krátce vrací v původní podobě v Es v krátkém úseku A" (t. 106114) a na něj navazuje dlouhý evolučně zpracovaný návrat dílu B' (115-172) v E vrcholící uvedením nového melodického prvku navrstveného na evolučně zpracovávaný tematický materiál dílu B. Tímto úsekem pomyslně vrcholí neofolklorní inspirace této věty:

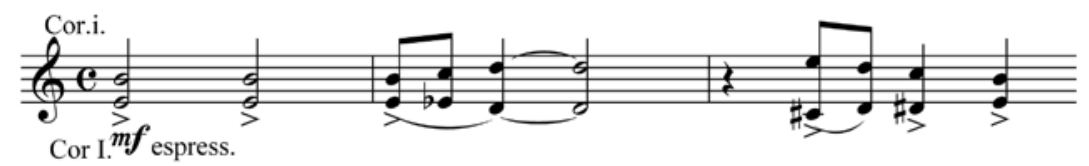

Př. 7 Tretí věta, t. 135-137.

Potřetí se díl A"' (t. 173-200) navrací v celém svém původním tvaru, avšak evolučně zpracovaný s vloženými krátkými motivickými reminiscencemi z oddílu C. Ten se poté samostatně podruhé vrací jako C"” v t. 201-332. V těsném připojení k C" se krátce navrátí v gradaci i díl B”, který zaznívá v druhé vrstvě nad tématem dílu C (t. 333-339).

Závěr věty tvoří coda v tempu Maestoso v Es (t. 340-355), jejíž motivický materiál spojuje ve třech vrstvách nad sebou témata všech tří oddílů.

Obecně lze o díle konstatovat, že se Novák v mikrotektonické výstavbě a v rámci rozvíjení evolučních ploch čerpajících z materiálu jednotlivých zřetelně oddělených témat (až na úseky inspirované Janáčkovým hudebním jazykem) příliš neodchyluje od klasické přísné motivicko-tematické práce s častým použitím kontrapunktických technik (imitace, kombinace), jak ji měl možnost recipovat na konzervatoři a později na HAMU a JAMU. Stylově rozrůzněné dílo, které Novákův klavírní koncert z roku 1947 představuje, je amalgámem bachovských neobarokních inspirací (vliv Novákova studia Bacha v roce 1946 a Bořkovce), názvuků romantismu a recepce Janáčka (Petrželka) dokládá Novákovo úporné hledání své vlastní poetiky.

\section{Novákovy úpravy koncertu po setkání s Martinů}

„[...] Našel se dnes konečně člověk, který mi řekl, že to mé concerto, na kterém jsem ztratil pomalu rok, nestoji za mnoho"7

Novák byl v době dokončení kompozice koncertu začátkem září 1947 s výsledným tvarem díla zjevně spokojen a ještě před setkáním s Martinů byl přesvědčen o jeho kvalitě, což dokládá jeho úvaha, kterou jsme již zmínili výše, o možnosti uvedení díla v premiéře Rudolfem Firkušným, v té době v USA úspěšně zavedeným světově uznávaným klavírním

7 NOVÁK, Poznámky, 8. 9. 1947. 
virtuózem. ${ }^{8} \mathrm{~V}$ tomto pozitivním rozpoložení přinesl Novák koncert na svou první hodinu u Martinů jako představení jeho aktuální kompoziční práce : „[...] Jelikož jsem měl dnes proní hodinu s Martinů, řekl jsem si, že mu to [klavírní koncert] ještě ukăžu, ač jsem si pươodně myslel, že už neni třeba, aby to ještě někdo vidèl, už to vidèlo lidí dost. “9 Novák zde vyslovuje to, co jsme konstatovali dříve o vlivu z více směrů a osobností (Bořkovec, Petrželka, snad také v závěru Copland?) v průběhu kompozice díla a také, že si byl vědom tohoto svého hledání, kým se nechat vést, a s tím souvisejících pochybností (viz výše citovaná Novákova formulace „našel se [...] konečně [zvýrazněno autory studie] člověě"). I když Novák Martinů dílo ani nepřehrál celé, Martinů trefně a lapidárně vystihl jeho kompoziční nedostatky: ,[...] Martinů, kterému jsem to jen částečně zahrál řekl, že je to: křčcovité a školni a klavirni technika neni dost brilantni a taky je to asi moc dlouhé. Tak jsem značně z té proni hodiny, confused " "10 Novákovo na vnějšek deklarované skladatelské sebevědomí tím značně narušil, což se ukázalo jako zásadní pro Novákův budoucí skladatelský vývoj. Ač byla kritika skladby ze strany Martinů drtivá a Novák zpočátku zcela rezignoval na jakékoliv úpravy: „[...] Ale ten koncert mne zatraceně mrzi. Nezměním na tom ovšem ani notu, to ho můžu hned hodit celý do záchodu. "," přece jen se do revize koncertu pustil, a to patrně nedlouho po oné první zásadní návštěvě Martinů. Ač nepíše Novák nic bližšího k tomu, co mu Martinů dále ke koncertu řekl, a jestli vůbec mu doporučil nějaké konkrétní úpravy, pustil se Novák do revize kompozice, a to zásadní, patrně také pod vlivem osobnosti Martinů, která ho přes drtivou kritiku jeho práce uchvátila: „Jsem zvědav, jak se vyvine můj dalši poměr $k$ Martinů. Vážím si ho i jeho muziky a neprestanu ho uznávat za velkého skladatele, $i$ kdybych se s ním třeba někdy rozešel. "12 Domníváme se však, že Martinů přece jenom Novákovi nějaké konkrétnější podněty pro revizi sdělil. Charakter změn provedených v koncertu je totiž zcela v souladu s metodou Martinů práce na revizi kompozice Partity jeho žačky Vítězslav Kaprálové, kterou s ní učinil v rámci jejího krátkého kompozičního školení, a které jsou známy poměrně podrobně. ${ }^{13}$ Úpravy, které Martinů navrhoval Kaprálové, byly převážně v oblasti tektoniky, v úpravě formálního plánu jednotlivých vět kompozice. Harmonický průběh nebo melodika ho takřka vůbec nezajímaly. Tentýž charakter úprav, který se týkal takřka výlučně tektonické výstavby jednotlivých vět, sledujeme i při Novákově vlastní revizi koncertu.

Revizi díla zanesl Novák do reprodukce autografní partitury a také do klavírního výtahu. V 1. větě Novák upravil napojení oblasti závěrečného tématu na provedení zkrácením dvou taktů v úseku mezi t. 219 a 220 a jednoho taktu před t. 224, kdy začíná provedení. V samotném provedení vyškrtl deset taktů před t. 286, které zpracovávaly motivy vedlejšího tématu. $\mathrm{V}$ repríze také provedl škrty $\mathrm{v}$ místech, kde nastupuje pouze sólový klavír: pět taktů před t. 326, po jednom taktu postupně před t. 346, 347, 348. Nejrozsáhlejší

$8 \quad$ Viz výše pozn. 3.

9 NOVÁK, Poznámky, 8. 9. 1947.

10 Tamtéž.

11 Tamtéž.

12 Tamtéž.

13 Viz BŘEZINA, Aleš. Eine „phantastische Schule“ des Komponierens für Streichorchester. Martinůs Eingriffe in die Partita (1938) von Vítězslava Kaprálová. In Schweizer Jahrbuch für Musikwissenschaft, neue Folge 17, 1997, s. 95-113. 
škrt v 1. větě představuje osmnáct taktů před t. 356 v evolučním zpracování reprízy vedlejšího tématu. Nepatrně také zasáhl do nástrojové stylizace sólového klavíru: v t. 148 a 149 vyškrtl akordickou figuraci v levé ruce a přidal oktávové zdvojení motivu pravé ruky, v úseku t. 208-219 upravil v pravé ruce držené čtvrtové oktávy na běhy osminových vzestupných oktáv a podobným zpơsobem v t. 280-283 v levé ruce půlových držené oktávy převedl do sestupných čtvrtových oktáv. Celou větu tak Novák zkrátil o 39 taktů.

Ve 2. větě vyškrtl celou osmitaktovou variaci před t. 49, která byla původně první variací po změně tempa na Poco più animato a před t. 108 vyškrtl celé dvě variace (16 taktů) před nástupem Tempo I., a původní předposlední variaci celé věty před t. 132. Úprava 2. věty byla citelnější, Novák z celkového počtu původních 173 taktů vyškrtl 32 taktů.

Ve 3. větě Novák zasahoval do rozrušování pravidelného metra a taktového členění: tak hned v úvodním dílu A krátí druhou polovinu t. 6, 8, 11, a první polovinu taktu v t. 14, 17, 19 a rozrušuje tak metrum 6/4 několika 3/4 vsuvkami. Nejvýraznější zásah $\mathrm{v}$ rámci 3. věty představují dva škrty při prvním návratu dílu $\mathrm{B}^{\prime}$. Jde o odstranění pěti taktů před t. 135 a sedmnácti taktů před t. 166. Jako v 1. větě, i zde Novák provádí ojedinělé drobné změny v nástrojové stylizaci sólového klavíru a upravuje nástup dílu $\mathrm{C}$ v levé ruce (viz př. 6 výše). 3. věta byla zkrácena o 22 taktů a 6 půltaktů.

Z výše uvedeného vyplývá, že Novák pracoval na úpravě tektonické výstavby jednotlivých vět a směřoval svými škrty k upevnění formální sevřenosti, což zemitě Martinů shrnul slovy ,je to asi moc dlouhé." Ač se intenzivně Novák touto podstatnou revizí snažil upravit dílo do podoby, s níž by byl po kritice Martinů spokojen, zdá se, že se mu to přes všechnu snahu v jeho očích nepovedlo a dílo přece jen hodil „celé do záchodu.“ Koncert proto nebyl nikdy proveden a ani Novák se potom o něm už nikdy nezmínil. Dle našeho názoru je to dílo, které dokládá krom Novákova úporného hledání svého vlastního kompozičního já, též jeho mimořádný talent, a jako takové by bylo vhodné jej př́ležitostně uvést na koncertním pódiu.

\section{Mistr můj, Martinů! - Koncert pro klavír a smyčcový orchestr (1949)}

\section{„[...] odměnou jsem brzy zřrel tvár̆ Mistra zjasněnou a získal přitele si Martinů."14}

Novákův životopisec a přítel Zdeněk Cupák uvádí jako rok dokončení Koncertu pro klavír a smyčcový orchestr rok 1949. ${ }^{15}$ Ve stejné době vznikaly např. Novákovy Variace na téma B. Martinu pro dva klavíry. Premiéra klavírního koncertu se uskutečnila 3. května 1950 na IX. orchestrálním koncertě Státní hudební a dramatické konservatoře v Brně v Besedním domě. Sólový part hrála Novákova manželka Eliška Nováková-Hanousková, orchestr řídil Bohumír Liška. Tomuto obsazení odpovídá i přípis učiněný tužkou na deskách

14 První sonet Jana Nováka z cyklu Sonety na B. Martinů. In ZOUHAR, Zdeněk (ed.). Bohuslav Martinů. Sbornik vzpominek a studii. Krajské nakladatelství v Brně, 1957, s. 40.

15 Strojopisný dodatek Zdeňka Cupáka in Konzert für Klavier und Streichorchester 1949 von Jan Novak, partitura, Zanibon: Padova, Archiv Konzervatoře Brno, sig. A 55246. 
partitury, která je uložena pod sig. A 55246 v archivu Konzervatoře Brno: „N. EliškaLiška B. “ Další provedení následovalo na Nočním koncertě 23. května 1950 v Čs. rozhlasu Brno se stejným dirigentem a sólistkou za doprovodu Brněnského rozhlasového orchestru. Repríza pořadu, ve kterém zazněla také Předehra Václava Lídla a Symfonietta Bohuslava Sedláčka se uskutečnila 18. července 1950. Nejnověji byl koncert nahrán v listopadu 2015 klavíristkou Alicí Rajnohovou za doprovodu Ensemble Opera Diversa pod taktovkou Gabriely Tardonové. ${ }^{16}$

\section{Formální plán}

Jde o třívětý cyklus s krajními rychlými a střední pomalou pastorální větou.

1. Allegro sostenuto (31 t.). Allegro con spirito (471 t.) - d moll, $3 / 4$ takt.

2. Andante pastorale (186 t.) - B dur, 6/8 takt.

3. Allegro (140 t.) - Un poco meno mosso (80 t.) - Tempo I. (218 t.) - d moll, 4/4 takt.

\section{1. věta (502 t.)}

Pro sonátovou formu první věty platí to, co Martinů říká o sonátové formě v polovině 20. století:

„Sonátová forma je dnes už všechno, co je přibližně třídílné s opakováním tématu. Schéma: myšlenka, provedeni a závěr - je trochu jednoduché a neřiká nic o vnitřních poměrech. Nicméně všechny rozbory jsou plné informací, kde výjimek je víc než pravidel. Sonátová forma, jež je vlastně trojúhelnik, zůstala (a často $i$ nezůstala) jenom primárni situace $A-B-A$ a vlastně jen titul. To, co dnes označujeme sonátovou formou, už ji dávno neni. "17

V tomto klavírním koncertu je obecně obtížné identifikovat témata, protože jejich charakter není př́lišs výrazný (obvykle se vyznačují jen charakteristickým sledem rytmických hodnot a tóninou), ale v toku okolní hudby často splývají.

Pro analýzu Novákova díla lze s úspěchem využít také pět stylových charakteristik (linií), které pro svá díla vymezil Sergej Prokofjev: ${ }^{18}$

- klasická - použití klasických forem, přehlednost sazby, výstavba témat apod.,

- novátorská - inovace v oblasti harmonie (disonance), melodiky a instrumentace,

- toccatová/motorická - využití pravidelných figurací, akordických rozkladů apod.,

- lyrická - rozvíjení zpěvných vět,

- groteskní - užívání scherzových až sarkastických poloh.

V prrípadě první věty je to styl toccatový, který je pro Novákovu klávesovou tvorbu příznačný. ${ }^{19} \mathrm{~S}$ Prokofjevem ho pojí i další charakteristické rysy. Působil jako koncertní klavírista (i když spíše v doprovodech a později v manželském duu), jako skladatel byl spíše lehký „mozartovský“ typ. Kromě toccatového stylu rychlých vět je to i časté užití

16 CD Jan Novák: Vol. 1. Ensemble Opera Diversa, 2015.

17 ŠAFRÁNEK, Miloš (ed.). Bohuslav Martinů: Domov, hudba, svět. Praha: SHV, 1966, s. 138.

18 PROKOFJEV, Sergej. Prokofjev: cesta k hudbě socialistického života. Ivan Vojtěch (ed.). Praha: SHV, 1961, s. $24-25$.

19 Srov. napřr. skladby Toccata chromatica či Inventiones per tonos XII ad., které vycházejí z Novákova studia bachovského kontrapunktu koncem druhé světové války. 
ironických až sarkastických poloh. Poznamenejme na tomto místě, že právě tyto polohy nejsou v předešlém koncertu přítomny vůbec.

\section{Expozice}

Hlavní téma zazní v introdukci Allego sostenuto (takt 1). Je v 3/4 taktu, motorické, d moll. Zcela zásadní pro další identifikaci v hudebním zápisu je jeho rytmická figura složená ze dvou osmin a jedné čtvrtové noty (1-1-2):

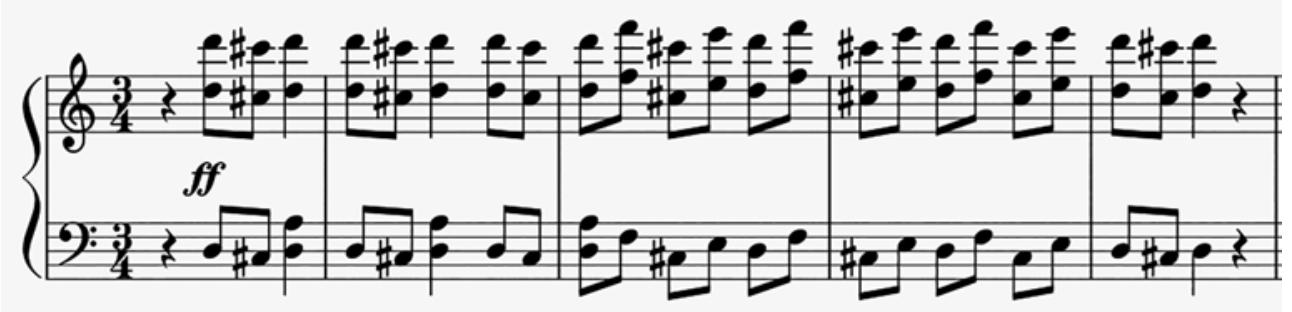

Př. 8 Hlavní téma (rytmický motiv) v orchestrální introdukci (od t. 1).

Sólový klavír poprvé vstupuje do orchestru už v 5. taktu sestupnou stupnicovitou kadencí. Tento vstup několikrát zopakuje.

V t. 32 (Allegro con spirito) se k orchestrální figuře přidá sekvencovité téma klavíru v d moll. Přitom není jasné, zda se jedná o samostatné téma, nebo klavírní součást tématu.

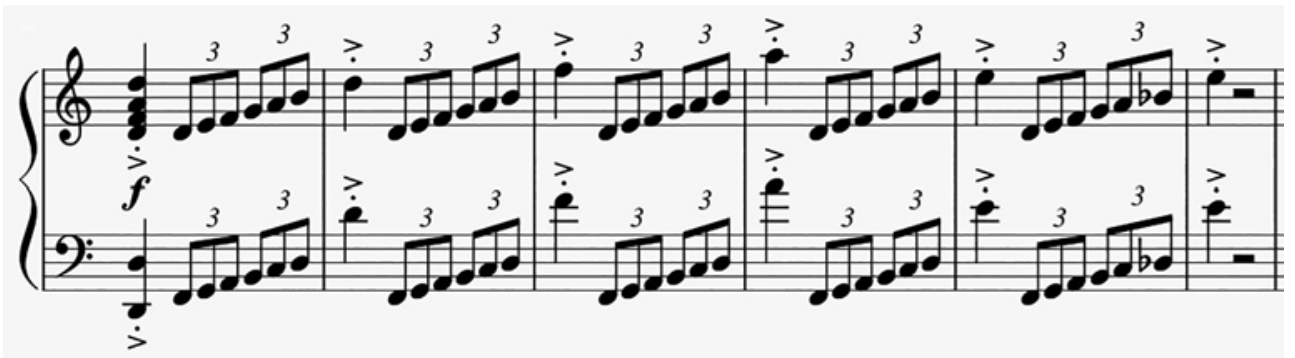

Př. 9 Klavírní část hlavního tématu, t. 32.

Později se obě témata, motivy nebo lépe řečeno charakteristické motivy objeví nad sebou, což napovídá tomu, že se jedná o součást jediného tématu.

Vedlejší téma (t. 127-148) - klavír doprovází zpěvné téma orchestru (v repríze se neopakuje, jen jeho závěr). Dochází k trojímu opakování tématu v Es/B/C dur (často dur proti moll - klavír vs. orchestr). Celé téma zazní až v t. 133 (v B dur, 3/4 taktu a dynamice $\mathrm{mp})$ : 


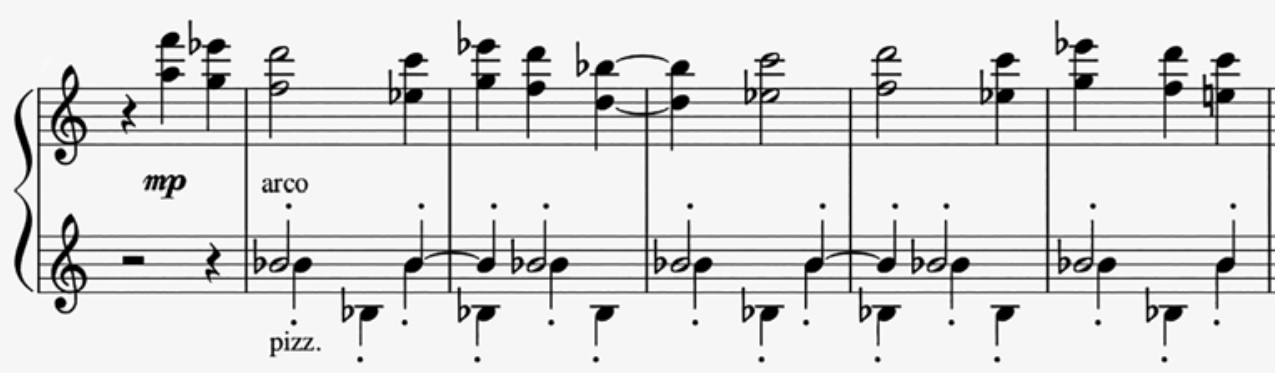

Př. 10 Vedlejší lyrické téma (t. 133) - Vn, Vla, Vcl.

Závěrečné téma je exponováno v A dur, 6/4 taktu, dynamice $p$ (t. 180):

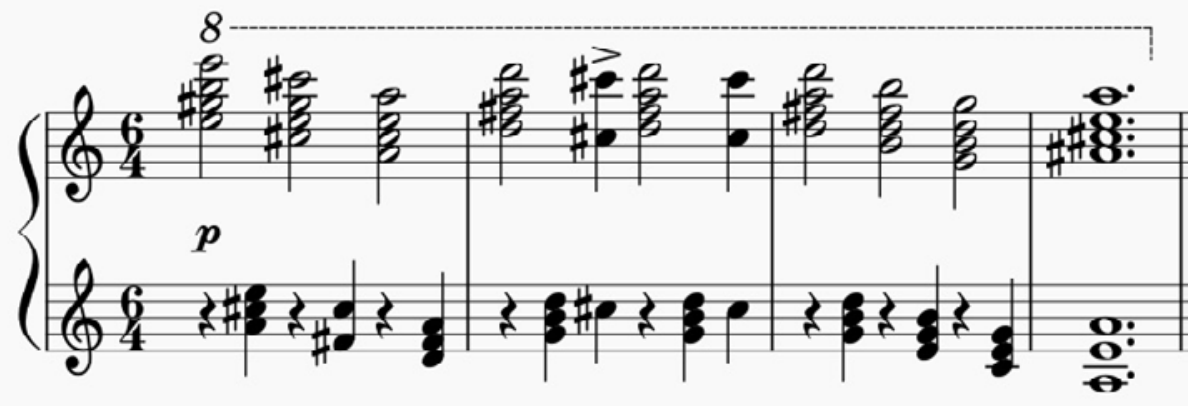

Př. 11 Závěrečné téma 1. věty.

Provedení začíná v t. 195 transpozicí hlavního tématu orchestru do fis moll a modulacemi do dalších tónin. Už od t. 217 se ale objevuje v basových linkách motiv hlavního tématu, který má zejména rytmickou (motorickou) funkci. Zhruba od t. 294 se provádí vedlejší téma.

Repríza je naznačena opakováním triolové klavírní části hlavního tématu v t. 357 v a moll. Do základní tóniny d moll se ale dostáváme až v t. 393. Částečné repríze vedlejšího tématu odpovídá t. 430, od kterého fragment tématu prochází několika tóninami. Závěrečné téma v D dur se objeví v t. 449. V závěru věty je využita tematická coda (Pesante), která vychází z hlavního tématu, tentokrát ovšem v B dur (t. 480-502).

\section{2. věta (186 $t$.)}

Druhá věta je martinůovské pastorale v B dur v 6/8 taktu. Ačkoliv se zdánlivě jedná o pomalou větu, trojí výskyt hlavní myšlenky ukazuje na velké rondo (schéma $\mathrm{A}-\mathrm{B}-\mathrm{A}-\mathrm{C}-\mathrm{A}$ ).

Sordinované smyčce spolu s klavírem přinášejí téma hned v 1. taktu: 


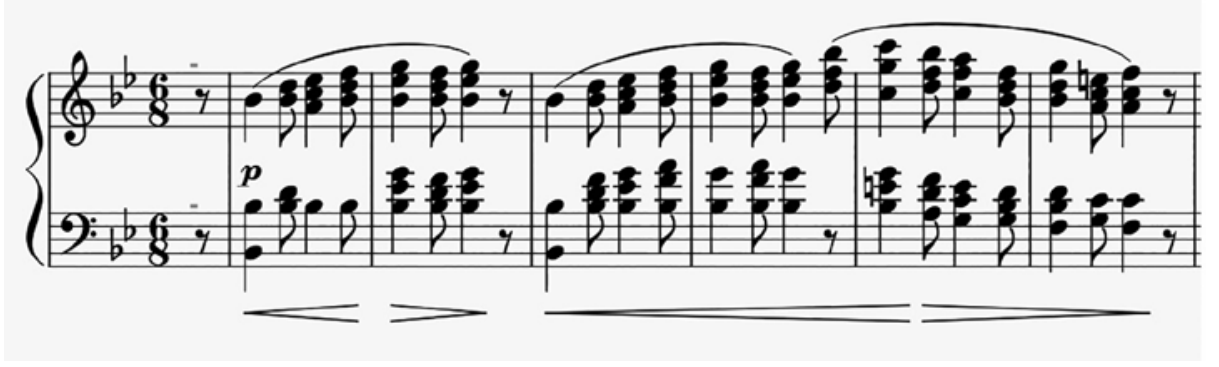

Př. 12 Andante pastorale - úvod 2. věty.

Proti němu je postavena hybná kontrastní sarkastická pasážová plocha v b moll, od t. 51. V t. 66 se navrací pastorální téma v C dur. Klavír ovšem proti němu staví rychlé triolové figurace. Takt 89 přináší akordické skoky klavíru proti šestnáctinovým pasážím orchestru. Pastorální téma v B dur se opět vrací v t. 142.

\section{3. věta (439 t.)}

Finální věta je v třídílné velké písňové formě: Allegro - Un poco meno mosso - Tempo I. (A-B-A).

Díl A bychom mohli rozdělit na dvě samostatná témata:

a) rytmické téma,

b) lyrické téma.

Allegro - je monotematická věta, vystavěná na charakteristické rytmické figuře.

1. Rytmické téma - t. 7 - d moll, figura dále použitá bud' jako 2-1-1 nebo v inverzi 1-1-2 (v šestnáctinách).

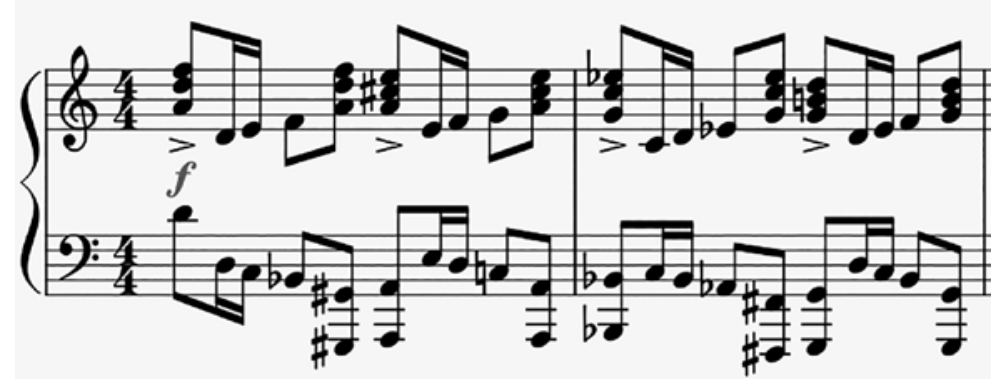

Př. 13 Rytmické téma (t. 7).

Rytmické téma pokračuje synkopickými plochami v d moll (t. 17) a v B dur ve smyčcích (Vn - Cb, t. 35). Naposledy se rytmické téma 2-1-1 v klavíru objeví v C dur v t. 70.

V osminách klavíru už slyšíme melodii, kterou v t. 106 převezme orchestr a vytvoří z něj nové lyrické téma $\mathrm{v} F$ dur nad původním rytmickým tématem klavíru: 


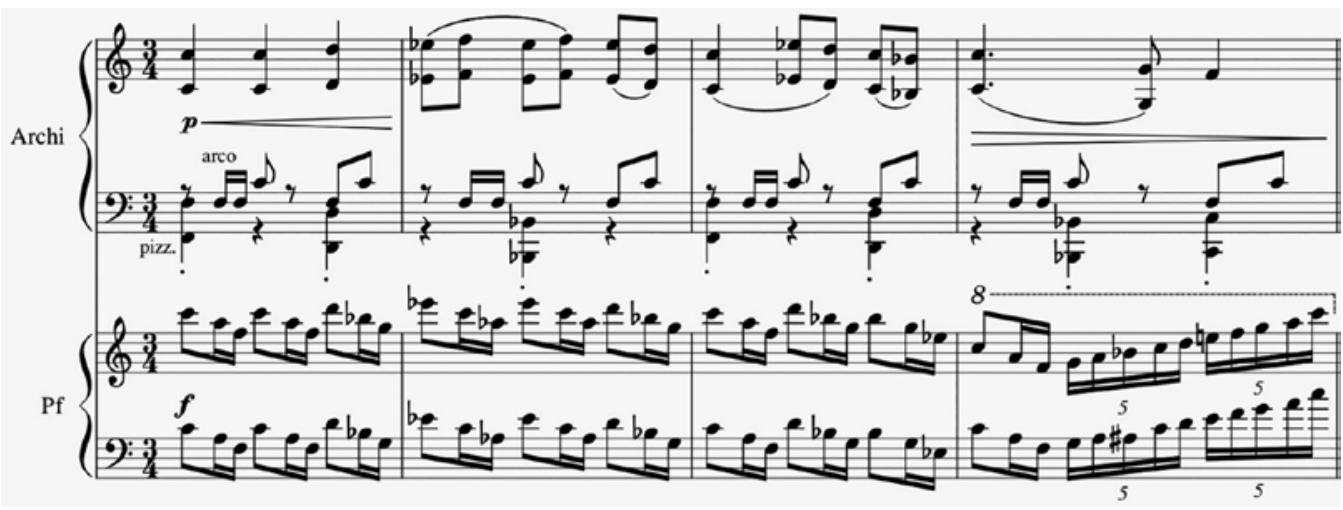

Př. 14 Lyrické téma orchestru (t. 106).

\section{Un poco meno mosso}

V t. 141 nastupuje kontrastní plocha Un poco meno mosso v d moll. Smyčce přinášejí v pianissimu neobarokní polyfonní plochu.

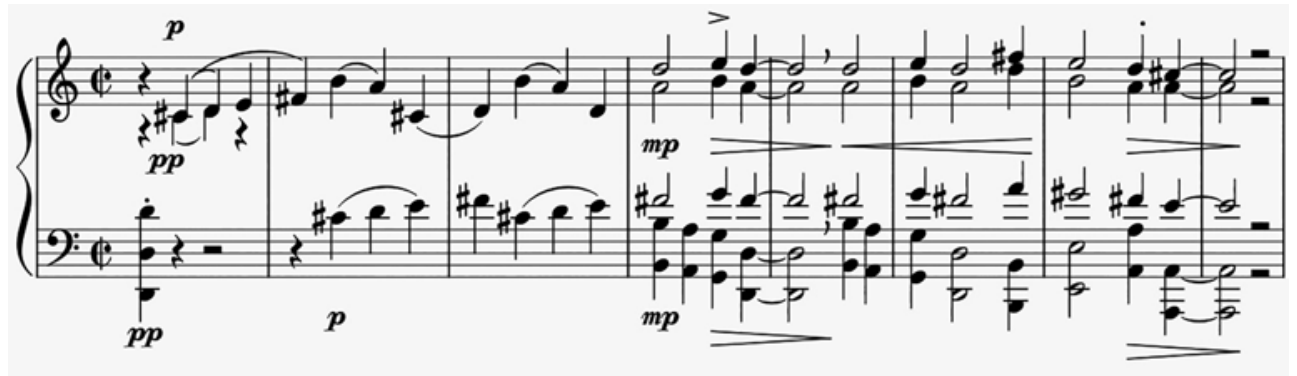

Př. 15 Kontrastní polyfonní plocha v t. 141.

\section{Tempo I.}

V t. 220 se vrací začátek 3. věty v původních tóninách. Vtip spočívá v tom, že to, co původně přinášel klavír, zde přináší orchestr. Sólový part se smyčci si zde tedy vlastně vymění hudební materiál. V t. 258 je vypsaná kadence klavíru (a capriccio) až do t. 314. V taktech 315-380 se reprízuje lyrické téma orchestru (z t. 106 v F dur) nyní ovšem v C dur a podložená figuracemi klavíru. V t. 346 se znovu se objevuje figura 2-1-1 v klavíru patřící rytmickému tématu.

Po vloženém dvoutaktovém Grave (t. 381-382) se vrací rytmizace prvního tématu a posledních 45 taktů je věnováno pokračování lyrického tématu. 


\section{Závěr analýzy}

Přes některé neobarokní inspirace (ovšem zcela odlišně pojaté), je zřetelné, jak odlišnou tvůrčí poetikou je vystavěno celé toto dílo, které působí mnohem uvolněnějším dojmem narozdíl od koncertu z roku 1947. Jako by celé dýchalo Martinů. Uved'me krátce několik shrnujích postřehů k Novákově inspiraci Martinů: v oblasti mikrotektoniky si Novák osvojil typickou motivickou práci Martinů rozvíjením tzv. cellul (buněk), krátkých motivů jak je Martinů nazýval (1. věta je vystavěna $\mathrm{z}$ „celluly“ $d$-cis-d-f-cis a jejích intervalových variant a rozvíjení). V harmonické i rytmické oblasti se vyskytují také typické martinůovské obraty: bitonální tritónové kombinace, synkopy a taktově nepravidelně vytvářené útvary. Charakteristická martinůovská polymelodická stavba za užití ostinátních motivů je taktéž přítomna, nemluvě o vstřebání martinůovské melodiky (např. vedlejší téma 1 . věty) a vůbec celkové větší formální uvolněnosti nikoliv ovšem na úkor sevřenosti celého díla.

Srovnáním obou děl spějeme k jednoznačnému závěru, že koncert z roku 1949 představuje pro Nováka jasné vykročení za svou vlastní tvưrčí poetikou cestou inspirovanou Martinů, Mistrem, kterého tehdy potřeboval nalézt a v něm konečně nalezl. Jak výstižně zní v kontextu srovnání obou děl Šafránkem zprostředkovaná vzpomínka Martinů na jeho rady Novákovi: „[...] veétši volnost, učil ho pracovat se synkopami, jak zmírnit turdé rysy harmonie, učil ho volnosti ve výraze “..$^{20}$

Tato studie vznikla diky podpoře GAČR v rámci projektu č́slo 19-06958S „Jan Novák a Bohuslav Martinů ve svètle vzájemné korespondence (1947-1959). Zpracováni a vydáni knižni monografie“.

Autoři děkuji také Pavlu Novotnému za zpř́stupněni pramenů Archivu Konzervatořre Brno $v$ době protiepidemických opatřeni.

\section{Bibliography}

BŘEZINA, Aleš. Eine „phantastische Schule“ des Komponierens für Streichorchester. Martinůs Eingriffe in die Partita (1938) von Vítězslava Kaprálová. In Schweizer Jahrbuch für Musikwissenschaft, neue Folge 17, 1997.

NOVÁK, Jan. Koncert pro klavír a velký orchestr. Partitura. Uloženo v Hudebněhistorickém oddělení

Národního muzea - Českého muzea hudby, bez signatury, přírůstkové číslo 141/1-4.

NOVÁK, Jan. Konzert für Klavier und Streichorchester 1949 von Jan Novak, partitura, Zanibon: Padova, Archiv Konzervatoře Brno, sig. A 55246.

NOVÁK, Jan. Poznámky z dopisů J. Nováka o lekcích u B. Martinů [rukopis]. Pozůstalost J. Nováka, ČMH Praha., New York, 8. 9. 1947.

20 ŠAFRÁNEK, Miloš. Bohuslav Martinů: Život a dilo [monografie]. Praha: Státní hudební vydavatelství, 1961, s. 279-280 cit. in ZOUHAR, Vít - COUFALOVÁ, Gabriela. Milý Miloši: Dopisy Bohuslava Martinů Miloši Šafránkovi. Praha: Univerzita Palackého, 2018, s. 575, pozn. 2659. 
PROKOFJEV, Sergej. Prokofjev: cesta k hudbě socialistického života. Ivan Vojtěch (ed.). Praha: SHV, 1961.

ŠAFRÁNEK, Miloš (ed.). Bohuslav Martinư: Domov, hudba, svět. Praha: SHV, 1966.

ŠTĚDROŇ, Miloš. Leoš Janáčcek a hudba 20. století. Brno 1998.

ZOUHAR, Zdeněk (ed.). Bohuslav Martinů. Sbornik vzpominek a studii. Krajské nakladatelství v Brně, 1957.

ZOUHAR, Vít - COUFALOVÁ, Gabriela. Milý Miloši: Dopisy Bohuslava Martinů Miloši Šafránkovi. Praha: Univerzita Palackého, 2018. 
